\title{
Histological and Hepatic Enzymes Response of Oreochromis niloticus and Clarias anguillaris to Pollution in Asa River, Ilorin
}

\author{
Segun Olayinka Oladipo ${ }^{1, *}$, Temidayo Daniel Adeniyi², Abass Toba Anifowoshe ${ }^{3,4}$ \\ ${ }^{I}$ Zoology unit, Department of Bioscience and Biotechnology, College of Pure and applied Sciences, Kwara State University, \\ Malete, Kwara State, Nigeria (olayinka_sgn@yahoo.co.uk) \\ ${ }^{2}$ Department of Medical Laboratory Science, University of Medical Sciences, Ondo city, Ondo State, Nigeria \\ (dtemidayo@unimed.edu.ng) \\ ${ }^{3}$ Department of Zoology, Faculty of Life Sciences, University of Ilorin, Ilorin, Kwara State, Nigeria (abassgenetics@ gmail.com) \\ ${ }^{4}$ Department of Molecular Reproduction Development and Genetics, India Institute of Science Bangalore, India \\ (anifowoshea@iisc.ac.in) \\ *Correspondence: olayinka_sgn@yahoo.co.uk
}

\begin{abstract}
Fish can be considered as a good organism for bio-indicator in aquatic habitats as they accumulate contaminant from the water bodies through food. Aquatic ecosystem pollutants response in fishes can lead to biochemical changes and histological alterations. This present the need in assessing ecological and public health effect of toxicity in Asa river on the selected fish samples that are commercially important in the environment. Two stations of Asa river were selected where water and fish were collected for physicochemical parameters of the water, enzymatic and histological investigations in the laboratory in April, 2019. The heavy metals of the water in Unity area of Asa river was higher than that of the standard limit and Asa reservoir. There was an increase in the ALT, AST and ALP biochemical analysis carried out on Oreochromis niloticus and Clarias anguillaris with reduction in total protein level in Unity station. The histopathology of the gills of both Clarias anguillaris and Oreochromis niloticus found in Unity station of Asa river revealed thinner and loner secondary lamella in degenerating secondary lamella and mildly distorted cartilage with epithelial lining in Clarias anguillaris. Hence, proper management of the river is necessary to restore the ecology and make the water fit for use.
\end{abstract}

Keywords: Asa River, Public Health, Histological, Management

Received: February 27, 2020 / Accepted: April 15, 2020 /Online: April 23, 2020

\section{INTRODUCTION}

Freshwaters serve as resources for agricultural activities, household and industrial applications (Anifowoshe et al., 2018). They are unavoidable in many sectors in the society and civilization needed in the kitchen for cooking, recreation and fishing activities (Orubu, 2006). The increase in population, industries, urbanization, improper environmental law awareness, non-implementation of environmental regulations, effluent discharge both from industries and households bring pressure on water resources and leads to aquatic pollution (Liyanage and Yamada, 2017). Most importantly, discharge of wastewater into the water bodies brings regression of water quality and causes serious problems to threaten the aquatic life resulting into negative effects on human systems and fish life activities (Bastami et al., 2015; Khalek et al., 2016). Among the problems of our priceless environment, pollution perks up the most interest; this is because the impact of pollution on a living organism is the most direct (Emre and Balogun, 2014).

Over the world, pollution is a challenge in the water environment (Aiman et al., 2016). Aquatic ecosystems were faced anthropogenic activities challenges as a result of a toxicant burden especially the heavy metals that naturally present in minute concentration, but its activities are toxic in higher concentration (Pandey et al., 2008; Ondarza et al., 2012; Pereira et al., 2013; Adeniyi et al., 2017). The pollutant of different forms can also have long persistence effects and accumulate in water and sediments having effects in the aquatic bodies' system equilibrium (Galadima et al., 2011; Monroy et al., 2014; Khalek et al., 2016). Aquatic organisms, such as fish, are used as a bioindicator in aquatic habitats due to the accumulation of pollutants in the water and indirectly via the food web (Findik and Cice, 2011). Due to protein content and other nutrient value, these fishes were consumed 
by humans but vulnerable as they cannot escape the pollution impact (Mahboob et al., 2014).

Response to industrial, sewage and agricultural pollutants in fishes can lead to histological changes in the muscle, gills, kidney and liver (Anifowoshe et al., 2018; Oladipo et al., 2018a). They can be used to know the sample of projected health effects of the entire population in the environment. The fish gills, liver, kidney and muscles resulted in many pathological alterations in various species as exposed to different toxicants (Benli et al., 2008; Osman et al., 2009; Syasina, 2011).

Fishes Oreochromis niloticus and Clarias anguillaris are important and economic freshwater fish species in Asa river, Ilorin, Nigeria. There widespread have been reported in different reservoir and river within the state, attributing it to their feeding ability on different food items, growing to a large size, high fecundity rate and ability to withstand a wide range of physicochemical conditions (Araoye, 2008; Öner et al., 2008; Mustapha, 2010; Authman et al., 2013; Oladipo et al., 2018b). This present research aims to assess the ecological and environmental health aspects of toxicity in Asa river by assessing its water quality parameters, as well as enzymatic and histopathological investigations of the selected fish samples, which that, are commercially important to human in the environment.

\section{MATERIALS AND METHODS}

\section{A. Sampling Stations}

The study was carried out on two different stations of Asa River. The first station is located at Unity where industrial and domestic waste discharge on the river and Aliara/Temioda town where the Asa dam reservoir lies that serves as the comparative control for the study (Figure 1).

\section{B. Sample Collection and Physicochemical Analysis}

Water samples were collected from two stations and analyzed for the physicochemical parameters. The $\mathrm{pH}$, electrical conductivity (EC) water temperature, and total dissolved solids (TDS) were calculated in situ on the water surface with the aid of Hanna portable pH/ EC/ TDS/ Temperature combined waterproof tester model HI 98129. The dissolved oxygen (DO), chemical oxygen demand (COD)biochemical oxygen demand (BOD) and some heavy metals such as lead $(\mathrm{Pb})$, chromium $(\mathrm{Cr})$, cadmium $(\mathrm{Cr})$, manganese $(\mathrm{Mn})$, and arsenic, were measured using Hanna multi-parameter for laboratories model (HI 83200) in hydrobiology and fisheries unit laboratory in the department of Zoology, University of Ilorin, Ilorin Nigeria.

Collection of the fish samples was done in the early hours (6:00-8:00am) in April 2019 with the help of a fisherman using basket and gill net. Fishes were transported to the laboratory using rectangular transparent plastics with a perforated covering to aid aeration and prevent escape.

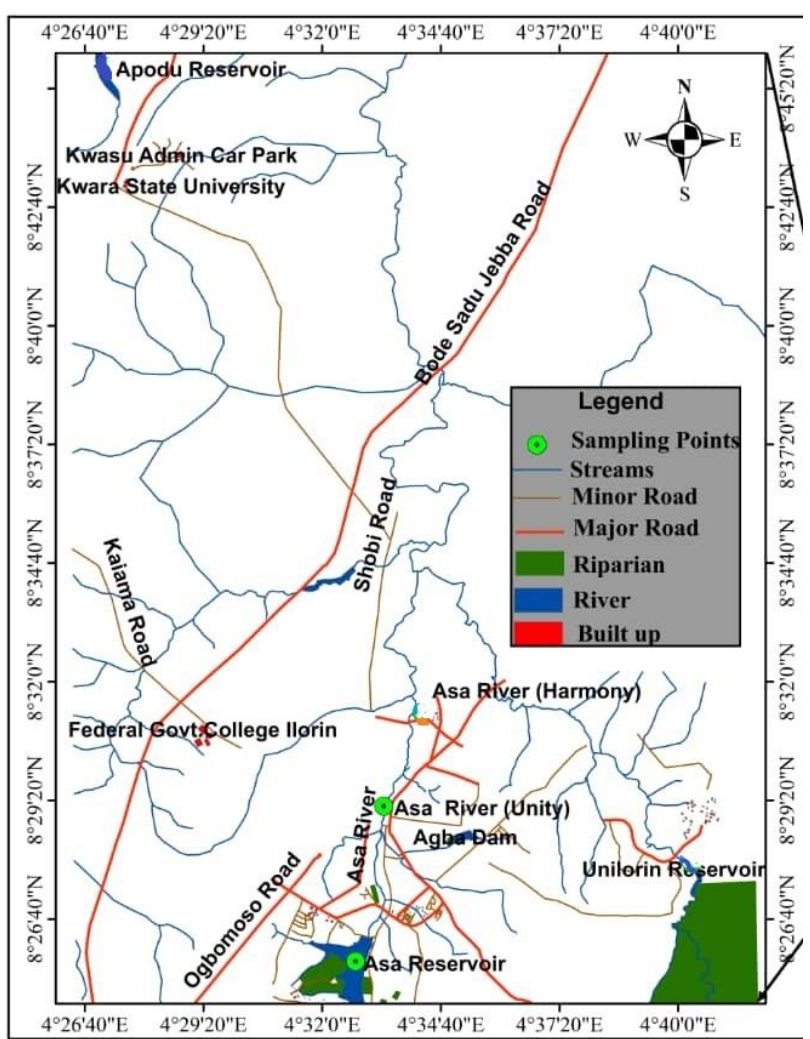

Figure 1. A geographical map of the Asa River segment showing the study area and sampling points.

Juvenile fish samples of $O$. niloticus and $C$. anguillaris were collected, selected for biochemical and histopathological analysis. The blood sample was collected through the caudal vein of the fish and stored in sample (EDTA) bottles. The analysis of biochemical enzymes, Alkaline phosphate (ALP); Aspartate aminotransferase (AST); Alanine aminotransferase and Total protein activities were assayed using the respective reagent kits (Reitman and Frankel, 1957).

Different tissues of gills and liver of the two fish species were also collected through dissection from both sampling point. The standard method of Gobinath and Ramanibai, (2014) was used with little modification. Briefly, the tissue samples collected after dissection were fixed in buffered formal saline for a day (24 hours) and rinsed vigorously with distilled water and process for paraffin tissue embedding using the method of Drury and Wellington (1980). The sections obtained from studied organs stained using hematoxylin and eosin $(\mathrm{H} \& \mathrm{E})$ using the standard procedure of Bancroft and Gamble (2008) and observed using an Olympus light microscope.

\section{Statistical Analysis}

The experimental values were presented as mean \pm standard deviation (SD). The Statistical Package for Social Science (SPSS) version 21.0 was applied to evaluate the differences between the test species and location. The multi-group comparisons of the mean were assessed out by one-way analysis of variance (ANOVA) test and the level of statistical 
significance were estimated at $\mathrm{p}<0.05$ using the Duncan multiple range test (DMRT).

\section{RESULTS}

$\mathrm{pH}$ for Aliara and Unity is lesser than the standard, COD and BOD for unity is higher than that of Aliara and the standard. While that of Aliara is equal to the standard. The amount of heavy metals (iron, magnesium, zinc, copper, lead, manganese, chromium, arsenic and cadmium) found in Asa river (Unity) is way higher than that of the standard limit and the reservoir. The control site had the same level of heavy metals as the standard (as depicted in Table 1).

Table 1: Physical and Chemical Properties of the Sampling Stations.

\begin{tabular}{llll}
\hline Parameters & $\begin{array}{l}\text { Asa } \\
\text { Reservoir }\end{array}$ & $\begin{array}{l}\text { Asa River } \\
\text { (Unity) }\end{array}$ & Who \\
\hline $\mathrm{pH}$ & 5.75 & 5.65 & $6.5-8.5$ \\
TDS mg/dl & 250 & 425 & 500 \\
Conductivity & 120 & 855 & - \\
Temperature & 31 & 31 & 25 \\
DO mg/dl & 4.1 & 5.94 & - \\
BOD mg/dl & 0.6 & 4.35 & - \\
COD mg/dl & 2128 & 5296 & - \\
Chromium ppm & 0.097 & 3.865 & 0.05 \\
Lead ppm & 0.45 & 2.699 & 0.05 \\
Cadmium ppm & 0.325 & 2.385 & 0.05 \\
Manganese ppm & 0.028 & 0.029 & - \\
Magnesium ppm & 0.000 & 4.635 & - \\
Arsenic ppm & 0.000 & 0.263 & - \\
Copper ppm & 0.250 & 1.283 & 1.0 \\
Iron ppm & 0.381 & 2.781 & 0.3 \\
Zinc ppm & 0.000 & 3.040 & 5.0 \\
\hline
\end{tabular}

WHO: World Health Organization; NESREA: National Environmental Standards and Regulations Enforcement Agency; USEPA: US Environmental Protection Agency.

The Biochemical parameters (ALT, AST, ALP and total protein) from selected $O$. niloticus and $C$. anguillaris fish were analyzed and were shown in Table 2. Biochemical analysis carried out on $O$. niloticus and $C$. anguillarisshow significant increase in Alanine aminotransferase (ALT), Alkaline phosphate (ALP) and Aspartate aminotransferase (AST) enzymes and significant reduction in total protein level (Hypoproteinemia) of fish species found in both Aliara and Unity stations. There was an increase in the value of the enzymes analysed for biochemical analysis in $O$. Niloticus than $C$. anguillaris.

Table 2. Biochemical Analysis of O. niloticus and C. anguillaris from the Sampling Stations.

\begin{tabular}{|c|c|c|c|c|c|}
\hline Site & Species & $\operatorname{ALP}(\mathrm{U} / \mathrm{I})$ & $\begin{array}{l}\text { Total protein } \\
(\mathrm{mg} / \mathrm{dl})\end{array}$ & $\operatorname{AST}(\mathrm{U} / \mathrm{I})$ & $\operatorname{ALT}(\mathrm{U} / \mathrm{I})$ \\
\hline \multirow{2}{*}{ 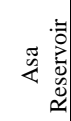 } & O. niloticus & $24.84 \pm 0.02^{\mathrm{c}}$ & $18.658 \pm 0.15^{\mathrm{b}}$ & $110.6 \pm 1.09^{\mathrm{a}}$ & $36.18 \pm 0.14^{\mathrm{a}}$ \\
\hline & $\begin{array}{c}C . \\
\text { anguillaris }\end{array}$ & $15.18 \pm 0.03^{\mathrm{a}}$ & $17.917 \pm 0.41^{\mathrm{b}}$ & $117.8 \pm 2.69^{b}$ & $34.32 \pm 0.42^{\mathrm{a}}$ \\
\hline \multirow{2}{*}{ 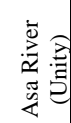 } & O. niloticus & $44.16 \pm 0.04^{\mathrm{d}}$ & $17.252 \pm 1.08^{\mathrm{a}}$ & $134.2 \pm 0.28^{\mathrm{c}}$ & $52.02 \pm 1.42^{\mathrm{b}}$ \\
\hline & $\begin{array}{c}C . \\
\text { anguillaris }\end{array}$ & $23.46 \pm 0.01^{\mathrm{b}}$ & $15.846 \pm 0.67^{\mathrm{a}}$ & $122.2 \pm 1.41^{\mathrm{b}}$ & $35.48 \pm 0.16^{\mathrm{a}}$ \\
\hline
\end{tabular}

Means within the same column with different superscripts differ significantly $(\mathrm{P}<0.05)$.
The representative photomicrograph of the gills of $O$. niloticus and $C$. anguillaris from Asa reservoir is shown in Figure $2 \mathrm{a}$ and $2 \mathrm{~b}$ indicating the secondary lamella (SL), blood vessels (BV) and supporting cartilages (CA) surrounding the blood vessels and holding the secondary lamella in place with no signs of pathological alterations. In Figure $3 \mathrm{a}$, the photomicrograph represents the gills of $O$. niloticus showing the (SL), BV and supporting CA surrounding the blood vessels and holding the secondary lamella in place. There are few signs of pathological alterations and the secondary lamella appears thinner and longer. The gills of $C$. anguillaris photomicrograph in Figure $3 \mathrm{~b}$ indicate the (SL), (BV) and supporting (CA) surrounding the blood vessels and holding the secondary lamella in place. They appear to be some pathological alteration in the histomorphology of the secondary lamella as they appear to be degenerating, distorted cartilage with epithelial lining.

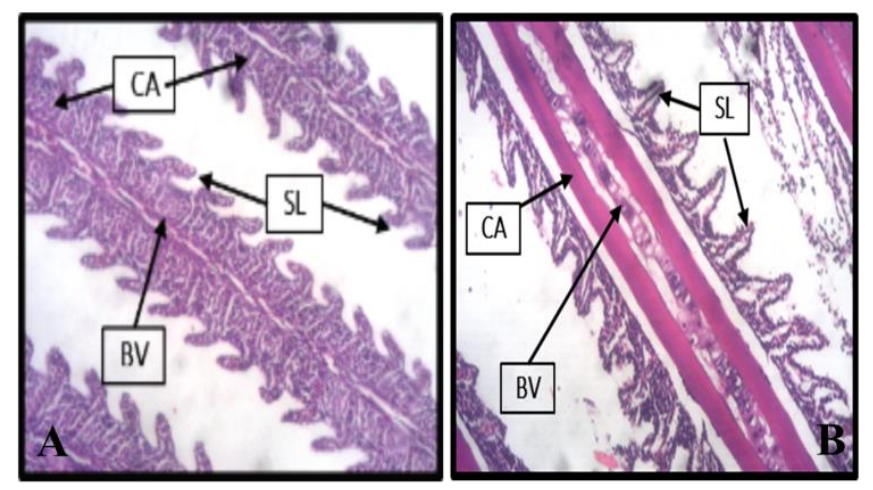

Figure 2. Histopathological Analysis of the Gills of Oreochromis niloticus (2a) and Clarias anguillaris (2b) in Aliara. Secondary Lamella (SL), Blood Vessels (BV) and Cartilage (CA).

Figure 4a, shows the photomicrograph of the liver of $O$. niloticus at high power magnification. Compactly crammed hepatocytes with intensively stained nuclei are seen evenly distributed in the liver tissue. There is no histopathological alteration.

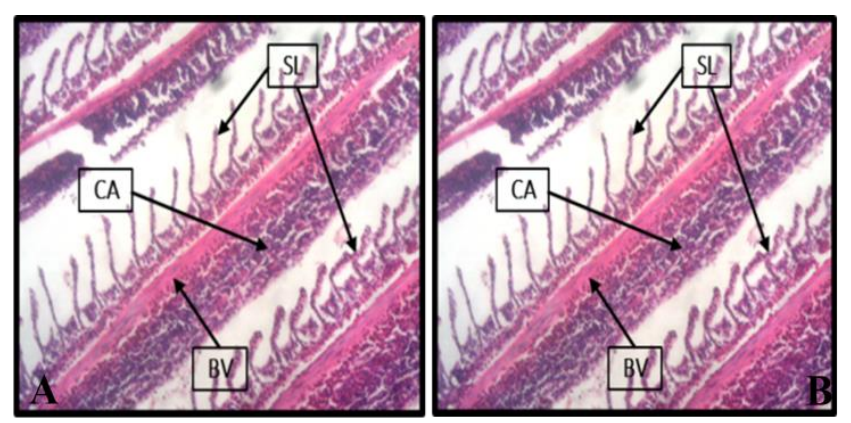

Figure 3. Histopathological Analysis of the Gills of O. niloticus(3a) and $C$. anguillaris (3b) in Unity. Secondary Lamella (SL), Blood Vessels (BV) and Cartilage (CA).

Figure 4brepresents the photomicrograph of the liver of $C$. anguillaris revealing the hepatocytes at the higher power magnification. Densely packed hepatocytes with intensively stained nuclei are seen evenly distributed in the liver tissue. There is no histopathological alteration. Whereas Figure 5a 
represents the photomicrograph of the liver of $O$. niloticus showing the densely packed hepatocytes with intensively stained nuclei being seen poorly distributed in the liver at high power magnification. There is a histopathological alteration as sinusoid dilation and distension, oedema and vacuolation while in $C$. anguillaris, photomicrograph of the liver in Figure $5 \mathrm{~b}$ shows the densely packed hepatocytes with intensively stained nuclei are seen evenly distributed in the liver tissue at high power magnification. There is similar histopathological alteration as observed in Figure 5a; sinusoid dilation and distension, oedema and vacuolation

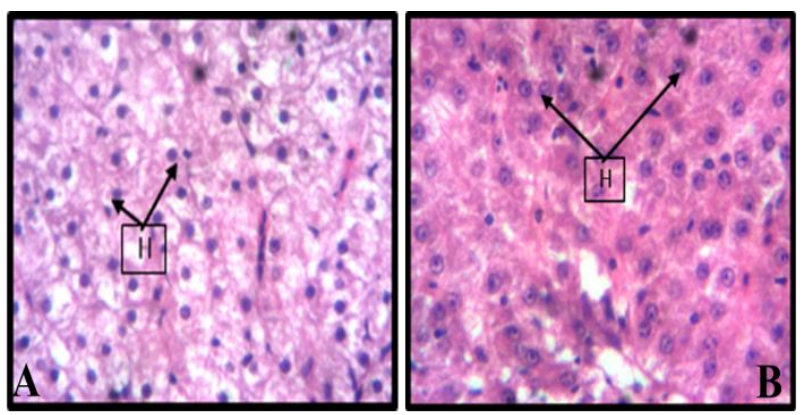

Figure 4. Histopathological Analysis of the Liver O. niloticus (4a) and $C$. anguillaris (4b)in Aliara. Hepatocytes $(\mathrm{H})$.
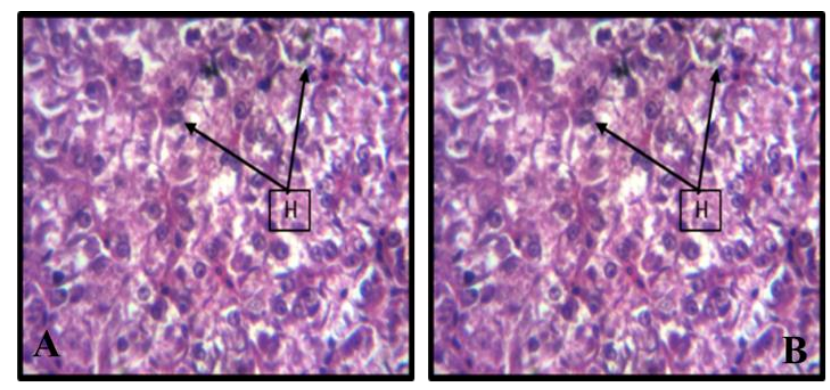

Figure 5. Histopathological Analysis of the Liver O. niloticus(5a)and $C$. anguillaris (5b)in Unity

\section{DISCUSSION}

Water contamination is caused directly or indirectly by human anthropogenic activities (Karadede et al., 2004). These contaminants pollute the water bodies and thus pose a threat to the life of aquatic organisms as well as human via drinking (Akpan and Ajayi, 2016).

The source of heavy metals at the Asa river study sites is mainly of exogenous origin (domestics, industrial and agricultural wastes) (Eletta et al., 2005). Since water plays a germane role in maintaining human health, the observations and level of physicochemical parameter above the standard limit might provoke the anomalies in the ecology and fauna present in the river (Mustapha, 2010). This may be due to the inappropriate release of industrial and household wastes continuously into the water body to elevate the aforementioned physicochemical parameters and therefore cause a detrimental long-time health effect in people and animals making use of the water (Almeida et al., 2002).
In the histopathology analysis, the liver of fish found in Asa reservoir exhibits a normal structure when compared with fish found in Asa river (Unity), which shows some lesions such as oedema and vacuolation. Oreochromis shows a mild effect in the liver tissue compared to Clarias. The gill, which is one of the vital organs, participates in many crucial roles such as respiration, osmoregulation (salt and water balancing), and excretion in the fish. Due to its sensitivity to changes in water quality, it is therefore considered as the primary target of contaminant because of its close contact with the external (Kranz et al., 1990). The gills represent the target organ for the toxicity of dissolved metals because they are the main site for entry for the surrounding element, the gill has a large surface and tiny epithelium making metals easily penetrate through it (Genten et al., 2009). Alteration in the histopathology of the gills of both scaled O. niloticus and C. anguillaris found in Unity station of Asa river revealed thinner and loner secondary lamella in degenerating secondary lamella and mildly distorted cartilage with epithelial lining in C. anguillaris as reported by authors being an effect of pollution on histology of vital organs in fishes (Al-Marjan and Abdullahi, 2016; Hamdamin et al., 2017; Oladipo et al., 2018a). This might be as a result of the presence of scales acting as a protective sheath to the fish and preventing toxicants from invading the fish body leaving only the gills for penetration and causing more effect on it which is consistent with the findings of Perkins et al. (1972).

The reduction in total protein at Unity as compared to Aliara is in line with the observations of El-Sheekh et al. (2011) who also reported a low protein level in fishes from a polluted environment. According to Fontana et al. (1998), the decrease may be due to the damage of protein-synthesizing subcellular structures and inhibition of the hepatic synthesis of blood protein. In this study, an elevation in ALT, ALP and AST enzymes was recorded in fishes found in Unity station than Aliara station which corroborates the study of Chen et al. (2004), who suggested that the increase indicates impairment of the liver, hepatocellular damage or cellular degradation. Hepatic cellular damage also leads to the leakage of these enzymes, which consequently led to their leakage or rupture into the blood circulation (Mouse et al., 2008). These findings also agree with the study of Fatma and Nahed (2000); Yamawaki et al. (1986) and Shalaby (2007).

The concentration of aquatic pollutant may be measured through water, sediment or organism present, since the accumulation of the constituent can induce abnormalities in the histology of the fish (Ademoroti 1996). The present result justified this effect of pollution in the liver and gill of the studied fish is in accordance with the studies that fish living inside polluted waters have higher frequencies of abnormalities and the abnormalities vary based on the kind of contaminants presents and the species of fish (Adekunle et al., 2008; Ogundiran et al., 2009).

It was reported that lower concentrations of heavy metals are usually accumulated in pelagic fish compared to the benthic fish (De Jonge et al., 2015). This has resulted in settling of 
the weighted metals in the water to settle down in the benthic region to accumulate more in the bottom dweller fishes than pelagic fishes, and closely related species can respond to the same given toxicants in different ways (Adelekan et al., 2011). This effect can be biomagnified in humans consuming those fish via food chains (Almeida et al., 2002).

\section{V.CONCLUSION}

The results of the physicochemical parameters and the effect of pollutants on $O$. niloticus and $C$. anguillaris from the Asa river using biochemical and the histopathology of gills and liver of the fishes reveal that the unity section of Asa river is polluted. This is due to domestic waste and industrial effluents discharge. Hence, proper management of the river is necessary to restore the ecology and make the water fit for use.

\section{ACKNOWLEDGEMENT}

We acknowledge B.B. Adetunmobi, E.C. Obiozor ${ }^{\dagger}$ and the people of Aliara/Temioda (the villagers) for the help during the sampling, hospitality and kind gesture.

\section{CONFLICT OF INTEREST}

We declare no conflict of interest.

\section{REFERENCES}

Abdel-Khalek1, A.A., Elhaddad, E., Mamdouh, S, Marie M.S. (2016) Assessment of Metal Pollution aroundSabal Drainage in River Nile and its Impacts on Bioaccumulation Level, Metals Correlation and Human Risk Hazard using Oreochromis niloticus as a Bioindicator. Turkish Journal of Fisheries and Aquatic Sciences, 16, 227-239.

Adekunle, A.S., Eniola, I.T.K. (2008). Industrial effluents on quality of segment of Asa River within an industrial estate in Ilorin, Nigeria. New York Science Journal, 1, 17-21.

Adelekan, B.A., Abegunde, K.D. (2011). Heavy metals contamination of soil and groundwater at automobilemechanic villages in Ibadan, Nigeria. International Journal ofPhysical Sciences, 6(5), 1045-1058.

Ademoroti, C.M.O. (1996). Standard methods for water and effluents analysis. Ibadan: Foludex Press Ltd. 3, 29-18.

Adeniyi, T.D., Achukwu, P.U., Abubakar, A.A. (2017). Frequency of electronics waste generated heavy metals in urban waterways. International Journal of Human Capital Urban Management, 2(2), 89100.

Aiman, U., Mahmood, A., Waheed,S., Malik,R. N. (2016).Enrichment, geoaccumulationandrisk surveillance of toxic metals for different environmentalcompartmentsfromMehmoodBooti dumping site, Lahorecity, Pakistan. Chemosphere, 144, 2229-2237.

Akpan D., Ajayi O. (2016). Adverse Effect of Water Contamination or Pollution to Human Health and Safety in the Nigeria Delta - Nigeria: An Environmental Case Study. Journal of Environment and Earth Science, 6(10), 2224-3216.

Al-Marjan, K.S.N., Abdullah, S.M.A. (2016). HistopathologicalChanges in Gills ofGoldfish, Carassius auratus (Linnaeus, 1758) Infested with Icthyophthiriusmultifiliis Fouquet, 1876 from Erbil Aquariums. ZANCO Journal of Pure and Applied Sciences, 28(3), 20-23.

Almeida, J.A., Diniz, Y.S., Marques, S.F.G., Faine, L.A., Ribas, B.O., Burneiko, R.C., et al., (2002). The use of the oxidative stress responses as biomarkers in Nile tilapia (Oreochromis niloticus) exposed to in vivo cadmium contamination. Environmental International, 27(8), 673-679.

Anifowoshe, A.T, Oladipo, S.O., Owolodun, O.A., Akinseye, M.K., Olafmihan, T.F., Sidiq, et al., (2018). Ecogenotoxicogical assessments of some selected fish species from Apodu reservoir, Malete, North Central, Nigeria. Manila Journal of Science, 11, 1-14.
Araoye, P. A. (2008). Physical factors and their influence on fish species composition in AsaLake, Ilorin, Nigeria.Revista de Biología Tropical, $57(1-2), 167-175$.

Ardila, J., Bijker, W., Tolpekin, V., Stein, A. (2012). Gaussian localized active contours for multitemporal analysis of urban tree crowns. Paper presented at the 2012 IEEE International Geoscience and Remote Sensing Symposium.

Authman, M.M.N., Abbas, H.H., Abbas, W.T. (2013). Assessment of metal status in drainage canal water and their bioaccumulation in Oreochromis niloticus fish in relation to human health. Environmental Monitoring and Assessment, 185(1), 891-907.

Bancroft, J.D., Gamble, H. (2008). Theory and practice of histological technique, 6th ed.Philadelphia: Churchill Livingstone/Elsevier, New York. 240p.

Bastami,K.D., Afkhami,M., Mohammadizadeh, M., Ehsanpour, M., Chambari, S., Aghaei, S., et al., (2015). Bioaccumulation and ecological risk assessmentofheavymetalsinthesedimentsand mulletLizaklunzingeriinthenorthernpartofthe Persian Gulf. Marine Pollution Bulletin, 94, 329-334.

Benli,A.C.K.,Koksal,G.,Ozkul,A.(2008). Sublethal ammoniaexposure of Nile tilapia(Oreochromis niloticus L). Effects on gill, liver, kidney histology. Chemosphere. 72, 1355-1358.

Chamara P. Liyanage, Koichi,Y. (2017). "Impact of Population Growth on the Water Quality of Natural Water Bodies," Sustainability, 9(8), 1-14.

Chen C., Wooster G.A., Bowser P.R. (2004). Comparative blood chemistry and histopathology of tilapia infected with Vibrio vulnificus or Streptococcus iniae or exposed to carbon tetrachloride, gentamicin or copper sulfate. Aquaculture, 239, 421-443.

David A. , Omoogun A. (2016). Adverse Effect of Water Contamination or Pollution to Human Health and Safety in the Nigeria Delta - Nigeria: An Environmental Case Study. Journal of Environment and Earth Science, 6,10.

De JongeM., Belpaire, C., Van Thuyne, G.Breine, J., Bervoets. L. (2015). Temporal distribution of accumulated metal mixtures in two feral fish species and the relation with condition metrics and community structure. - Total Environment, 407(13), 4047-4055.

Drury, R.A., Wellington, E. A. (1980). Carleton Histological Technique. 5th ed. New York: Oxford University Press. 190p.

Eletta, O.A., Adekola, F.A., Aderanti, M.A. (2005). Assessment of Asa River: Impact of waste discharge from soft drink plant into Asa River, Ilorin. Nigerian J. Appl. Sci. Environ. Mgt. 9,187-190.

El-Sheekh, M.M., El-Otify, A.M., Saber, H. (2011). Alterations in proteins and amino acids of the Nile cyanobacteria Pseudanabaena limnetica and Anabaena wisconsinense in response to industrial wastewater pollution. Braz. arch. biol. technol., 54, 4.

Emre, M.C., Balogun, J.K. (2014). Histopathology of Clariasgariepinus fingerlings exposed to Kaduna textile limited effluents. International Journal of Fisheries and Aquatic Studies. 2(2), 256-260.

Fatma, A.S., Nahed, S.G. (2000). Environmental Pollution induced Biochemical changes in Tissues of Tilapia zilli; Solea Vulgaris and Mugil Capito from lake Qarum; Egypt. GlobalVeterinaria, 2(6), 327336.

Findik, O., Cicek, E. (2011). Metal concentrations in two bioindicator fish species, Merlangiusmerlangus, Mullus barbatus, captured from the West Black Sea Coasts (Bartin) of Turkey. Bulletin of Environmental Contamination and Toxicology, 87(4), 399-403.

Fontana, L., Moreira, E., Torres, M., Ferna'ndez, I., Rios, A., Sanchezde, M.F., et al., (1998). Dietary nucleotides correct plasma and liver microsomal fatty acids alterations in rats with liver cirrhosis induced by oral intake of thioacetamide,Journal of Hepatology, 28, 662-669.

Galadima, A., Garba, Z.N., Leke, L., Almustapha, M.N., Adam, I. K. (2011). Domestic Water Pollution among Local Communities in Nigeria. Causes and Consequences. European Journal of Scientific Research, $5(2), 592-603$.

Genten, F., Terweinghe, E., Danguy, A., (2009). Atlas of fish histology. Enfield (NH): Science publisher. Accessed on January 21 ${ }^{\text {st }}, 2019$ from https://www.worldcat.org/title/atlas-of-fishhistology/oclc/679316913.

Gobinath, J., Ramanibai, R. (2014). Histopathological studies in the gill, liver and kidney of the freshwater fish LabeoRohita fingerlings. International Journal of Innovative Research in Science, Engineering and Technology, 3(3), 10296. 
Hamdamin, P.S.,Rasul, K.H., Aziz, F.M. (2017). Histopathological Effects of Methomyl Pesticide and Mobile Phone Electromagnetic Radiation on Duodenum of Male Albino Rats. ZANCO Journal of Pure and Applied Sciences, 29 (4); 1-11.

Hanna, X. F., Richard, J. (2018). Hall Brief communication: Recent changes in summer Greenlandblocking captured by none of the CMIP5 modelsEdward. The Cryosphere, 12, 3287-3292.

Jörundsdóttir, H.Ó., Jensen, S., Hylland, K., Holth, T. F., Gunnlaugsdóttir, H.,Svavarsson, J., et al., (2014). Pristine Arctic: Background mapping of PAHs, PAH metabolites and inorganic trace elements in the NorthAtlantic Arctic and sub-Arctic coastal environment. Science of the Total Environment, 493, 719-728.

Karadede, H., Oymak, S.A., Ünlü. E. (2004). Heavy metals in mullet, Liza abu, and catfish,Silurustriostegus, from the Atatürk Dam Lake (Euphrates), Turkey. Environment International, 30(2), 183-188.

Kranz, H., Dethlefsen, V. (1990). Liver anomalies in dab Limandalimanda, from thesouthern North Sea, with special consideration given to neoplastic lesions. Diseases of Aquatic Organisms, 9, 171-85.

Lushchak, V. (2011).Environmetally induced oxidative stress in aquatic animals. Aquatic Toxicology, 101(1), 13-30.

Mahboob, S., Al-Balawi, H.F.A., Al-Misned, F., Alquraishy, S., Ahmad, Z. (2014). Tissue metal distribution and risk assessment for important fish species from Saudi Arabia. Bulletin of Environmental Contamination and Toxicology, 92, 61-66.

Mekkawy, A.A., Mahmoud, U.M., Wassif, E.T., Naguib, M. (2011). Effects of cadmium on some haematological and biochemical characteristics of Oreochromis niloticus (Linnaeus, 1758) dietary supplemented with tomato paste and vitamin E. Fish Physiology and Biochemistry, 37, 7184.

Monroy, M., Maceda-Veiga, A., De Sostoa, A. (2014). Metal concentration in water, sediment and four fish species from Lake Titicaca reveals a large-scale environmental concern. Science of the Total Environment, 487, 233-244.

Mouse, M.M.A, El-Ashram, A.M.M., Hammed, M. (2008). Effects of Neem leaf extract on Freshwater fishes and zooplankton Community. 8th international Symposium on tilapia in Aquaculture The Central laboratory for Aquaculture research, cairo Egypt 12-14.

Mustapha, M.K. (2010). Fish fauna of Oyun Reservoir, Offa, Nigeria. Journal of Aquatic Science, 25(1), 106-114.

Ogundiran, M.A., Fawole, O.O., Adewoye, S.O., Ayandiran, T.A. (2009). Pathologic lesions in the gills of Clarias gariepinus exposed to sublethal concentrations of soap and detergent effluents. Journal of Cell and Animal Biology, 3(5), 78-82.

Oladipo, S.O., Mustapha, M.K., Suleiman, L.K., Anifowoshe, A.T. (2018b). Fish Composition and Diversity Assessment of Apodu Reservoir, Malete, Nigeria. International Journal of Fisheries and Aquatic Studies, 6(2), 89-93.

Oladipo, S.O., Anifowoshe, A.T., Olafimihan T.F (2018a). Assessment of Histopathological Damages in Swiss Albino Male Mice Induced by Automobile Waste Leachate. Animal Research International, 15(1), $2944-2949$.

Ondarza, P.M. Karina, M.G., Miglioranza, S.B.(2012). Increasing levels of persistent organic pollutants in rainbow trout (Oncorhynchus mykiss) following a mega-flooding episode in the Negro River basin, Argentinean Patagonia. Science of The Total Environment, 419, 233239.

Öner, M., Atli, G., Canli, M. (2008). Changes in serum biochemical parameters of freshwater fish Oreochromis niloticus following prolonged metal $(\mathrm{Ag}, \mathrm{Cd}, \mathrm{Cr}, \mathrm{Cu}, \mathrm{Zn})$ exposures. Environmental Toxicology and Chemistry, 27, 360-366.

Orubu C.O. (2006).Water Resources, Environment and SustainableDevelopment in Nigeria. Journal of Human. Ecology, 19(3), 169-181.

Osman, D., Gobert, V., Ponthan, F., Heidenreich, O., Haenlin, M., Waltzer, L. (2009). A Drosophila model identifies calpains as modulators of the human leukemogenic fusion protein AML1-ETO.Proc. Natl. Acad. Sci. U.S.A. 106(29), 12043-12048.

Pandey S., Parvez, S., Ahamd, R., Ali, A.M.,Kaur, M., Hayat, F. Ahmaand, F., Raisuddin, S.H. (2008). Effects of exposure to multiple trace metals on biochemical, histological and ultrastructural features of gills of a freshwater fish, ChannapunctataBloch.Chemico-Biological Interactions, 174(3), 183-192.
Pereira S., Pinto, A.L. Cortes, R., Fontaínhas-Fernandes, A., Coimbra, A. M., Monteiro, S.M.(2013). Gill histopathological and oxidative stress evaluation in native fish captured in Portuguese northwestern rivers.Ecotoxicology and Environmental Safety, 90, 157-166.

Perkins, E. J., Gilchrist, J.R.S., Abbott,O.J. (1972). Incidence of epidermal lesions in fish of the north-east Irish Sea area 1971. Nature, London, $238,101-3$.

Reitman, S., Frankel, S. (1957). Colorimetric determination of glutamic oxaloacetic and glutamic pyruvic transaminases. Am. J. Clin. Pathol. $28,53-56$.

Sekabira K., Oryem-Origa,H.,Basamba, T. A., Mutumba, G., Kakudidi. E. (2010). Assessment of heavy metal pollution in the urban stream sediments and its tributaries. - International Journal of Environmental Science and Technology, pp 7, 435-446.

Shalaby, A.M.E. (2007). Effect of EDTA on toxicity reduction of cadmium in relation to growth, some haematological and biochemical profiles of Nile tilapia (Oreochromis niloticus). J. Fish. Aquatic Sci. 2(2), 100109.

Syasina, I.G. (2011). Histopathology of Modiolus modiolus infected with green microalga, in: Cipriano, R.C., Bruckner, A.W., Shchelkinov, I.S. (Eds.), Bridging America and Russia with Shared Perspectives an Aquatic Animal Health. Proceedings of the Third Bilateral Conference between Russia and the United States, 12-20 July, 2009, Shepherdstown, USA, WV. Khaled bin Sultan Living Oceans Foundation, Landover, MD, pp. 56-62.

Yamawaki, K., Hashimoto, W., Fujii, K., Koyama, J., Ikeda, Y., Ozaki, H. (1986). Hematological changes in carp exposed to low cadmium concentration. Bulletin of the Japanese Society for the Science of Fish,59 (3), 459- 466. 